\title{
Risiko Dehumanisasi pada Crowdfunding sebagai Akses Pendanaan Berbasis Teknologi di Indonesia
}

\author{
Gita Widi Bhawika \\ Departemen Manajemen Teknologi, Fakultas Bisnis dan Manajemen Teknologi, Institut Teknologi Sepuluh \\ Nopember, Surabaya, 60264 \\ gita@mmt.its.ac.id
}

Diterima: 30 Mei 2017

Direview: 14 Juni 2017

Diterbitkan: 30 Juni 2017

Hak Cipta @ 2017 oleh Penulis (dkk) dan Jurnal Sosial Humaniora (JSH)

*This work is licensed under the Creative

Commons Attribution International License (CC BY 4.0).

http://creativecommons.org/licenses/by/4.0/ Open Access
Subject Areas: Management of Technology, Dehumanization

\begin{abstract}
Crowdfunding is the novel phenomenon. This fundraising based technology has increased its popularity since a decade ago. Crowdfunding can help people to funding their initiatives without boundaries because it only need internet connection to ask and give money. It is not necessary to gain relationship between initiator and funder. Yet, from the conventional fundraising point of view, it is important to build relationship to increase the loyal funder who can easily fund the future initiator's initiatives. Thus, crowdfunding has potential dehumanization risks. This descriptive research will discuss about crowdfunding in Indonesia, and its dehumanization risks. Moreover, this paper will describe crowdfunding phenomenon in Indonesia and also propose the model of crowdfunding's donor relationship management to minimize the dehumanization risks.
\end{abstract}

Keywords: Crowdfunding; Technology; Crowdfunding's Donor Relationship Management; Dehumanization.

\section{Pendahuluan}

Sedikit yang mengetahui crowdfunding, yang merupakan sebuah fenomena baru di dunia, yakni penggalangan dana berbasis teknologi untuk membantu pendanaan pada berbagai aktivitas, baik bisnis maupun aktivitas sosial. Crowdfunding diyakini mampu mendanai berbagai aktivitas yang sulit dilakukan oleh akses pendanaan konvensional, seperti bank dan investor yang prosesnya memerlukan berbagai persyaratan dan melalui birokrasi yang panjang.

Kelebihan dari crowdfunding, yaitu proses pengaksesan dananya sangatlah mudah. Pada dasarnya, penggalang dana hanya mempublikasikan aktivitasnya yang butuh didanai dalam bentuk proposal secara daring (online) dengan mencantumkan jumlah dana yang dibutuhkan. Untuk mempermudah, biasanya pemohon dana mempublikasikannya melalui pihak ketiga, yaitu penyedia layanan atau platform crowdsourcing, meskipun beberapa pemohon dana dapat mempublikasikannya secara mandiri. Lalu crowd (donatur potensial/penyandang dana), yang mengakses laman website dengan konten proposal tersebut, jika tertarik mendanai, mereka akan menyumbangkan atau meminjamkan dananya sesuai 
dengan klausul proposal daring yang telah dipublikasikan.

Kesuksesan besar terjadi pada beberapa inisiasi aktivitas crowdfunding di luar negeri, seperti proyek riset, pengembangan, dan penjualan jam tangan cerdas Pebble dan produk Opal oleh FirstBuild melalui platform crowdfuding Kickstarter (Brown, Boon, \& Pitt, 2016). Proyek jam tangan cerdas Pebble diinisiasi dengan tujuan untuk mengakses modal. Proyek ini berhasil mencapai target pendanaan dalam waktu 2 jam oleh 70.000 pendana individual (Brown et al., 2016). Selain itu, tenarnya platform crowdfunding di luar negeri, seperti Kickstarter, IndieGogo, dan Crowdfunder UK, menggerakkan semangat crowdfunding di Indonesia beberapa tahun belakangan ini, ditandai dengan berdirinya berbagai platform crowdfunding lokal, seperti KitaBisa, Wujudkan, dan GandengTangan serta tumbuhnya inisiasi melalui platform tersebut.

Di lain pihak, mulai tumbuhnya crowdfunding di Indonesia memicu suatu pemikiran mengenai potensi risiko crowdfunding, terutama pada sisi yang belum pernah dibahas pada penelitian-penelitian sebelumnya, yaitu risiko dehumanisasi.

Dehumanisasi merupakan penyangkalan esensi kemanusiaan yang meliputi atribut khas dan kodrat manusiawi menurut Nick Haslam dalam Nugroho (Nugroho, 2011). Penyangkalan terhadap atribut khas manusiawi menyebabkan satu pihak memandang pihak lain seperti binatang. Sementara penyangkalan terhadap kodrat manusiawi menyebabkan manusia diperlakukan seperti mesin (Nugroho, 2011).

Perubahan dan kemajuan jaman dengan perkembangan teknologi dan inovasinya serta masuknya era globalisasi ternyata dibarengi dengan salah satunya adalah keterasingan manusia satu dengan yang lain (Nugroho, 2011).

Seperti halnya perkembangan teknologi pada umumnya, crowdfunding berbasis teknologi ini berpotensi menimbulkan risiko dehumanisasi. Tidak seperti penggalangan dana konvensional, crowdsourcing tidak memerlukan interaksi secara langsung. Kedua belah pihak, yaitu penggalang dana dan penyandang dana hanya perlu berhadapan dengan gawai (gadget) masing-masing untuk mengajukan proposal dan menerima dana bagi penggalang dana, serta memilih proposal dan mendanainya bagi penyandang dana. Tidak ada interaksi humanis selama proses crowdfunding berlangsung. Dikhawatirkan, penyandang dana tidak menjadi loyal, atau penyandang dana yang loyal akan berkurang, karena lemahnya hubungan interpersonal antara kedua belah pihak.

Oleh sebab itu, penelitian ini akan mengenalkan crowdfunding, membahas fenomena crowdfunding di Indonesia, dan menganalisis potensi risiko dari crowdfunding yang mengerucut pada risiko dehumanisasi. Selanjutnya, solusi untuk meminimalisasi risiko dehumanisasi juga ditampilkan dalam suatu model manajemen donatur crowdfunding (Donor Relationship Management).

\section{Kajian Literatur Terdahulu}

Crowdfunding merupakan fenomena yang baru, tidak mengherankan bahwa literatur sebelumnya sangat terbatas (Belleflamme, Lambert, \& Schwienbacher, 2013).

Belleflame, dkk. (Belleflamme et al., 2013) meneliti mengenai pilihan entrepreneur sebagai penggalang dana dan investor sebagai penyandang dana pada skema crowdfunding yang paling banyak dipakai saat ini, yaitu pre-ordering dan profit- 
sharing. Hasil penelitian mengungkapkan bahwa enterpreneur dengan modal terbatas lebih menyukai skema pre-ordering dan sebaliknya, entrepreneur dengan modal besar lebih menyukai skema profitsharing. Belleflame, dkk. memberikan wawasan tentang kapan sumbangan bisa menjadi bentuk crowdfunding yang layak (Belleflamme et al., 2013). Belleflame dkk. juga menekankan pentingnya membangun komunitas penggalang dan penyandang dana agar crowdfunding lebih menguntungkan daripada penggalangan dana tradisional (Belleflamme et al., 2013).

Brown, dkk. (Brown et al., 2016) meneliti sejauh mana platform crowdfunding dapat diakses organisasi (penggalang dana) sebagai media pemasaran serta peranan yang dilakukan oleh organisasi tersebut dengan cara mempertimbangkan jumlah inisiatif/kampanye yang dilakukan oleh organisasi, menentukan motivasi organisasi dan cara mereka melakukan inisiasi melalui crowdfunding. Selain itu, Brown, dkk. (Brown et al., 2016) menyusun diagram keputusan untuk membantu para manajer pemasaran dalam menentukan pilihan skema crowdfunding yang akan diimplementasikan saat bekerja sama dengan platform crowdfunding.

Forbes dkk. meneliti pada tahap pengembangan proyek (inisiatif) crowdfunding dengan menyusun suatu panduan agar proyek crowdfunding berhasil. Penelitian dilakukan dengan metode kualitatif melalui wawancara dengan responden yang memiliki pengalaman sebagai pemberi dana pada proyek crowdfunding sebelumnya. Crowdfunding Success Tool yang disusun (Forbes \& Schaefer, 2017) antara lain:

1. Memilih platform crowdfunding yang tepat.

Berdasarkan nilai investasi sosial, besaran komunitas yang mendapatkan manfaat dari proyek, dan nilai risiko proyek, maka penggalang dana dapat menentukan platform mana yang akan dipilih, dalam hal ini platform crowdfunding skala global dan nasional (di Britania Raya) seperti Kickstarter, IndieGoGo, atau Crowdfunder UK.

2. Menentukan target pendanaan yang tepat. Disarankan untuk tidak mematok target terlalu tinggi dikarenakan kegagalan pencapaian target akan berdampak pada turunnya reputasi perusahaan.

3. Pilihan penghargaan (reward)

Hambatan utama investasi adalah harga, sehingga mengurangi marjin keuntungan pada pilihan penghargaan paling populer untuk meningkatkan jumlah pemberi dana.

4. Video Proyek/Inisiatif

Aspek yang perlu diperhatikan adalah konten video yang berisi informasi penting yang dapat dipahami pemberi dana, presenter video, dan struktur, dimana informasi diberikan pada awal video lalu dilanjutkan dengan motivasi dan inspirasi untuk proyek. Hal ini disebabkan umumnya responden kehilangan ketertarikan terhadap tayangan video setelah 30 detik penayangan.

\section{Literature gap}

Hampir semua literatur membahas mengenai dampak positif dari pelaksanaan crowdfunding, terutama untuk inisiatif/proyek berbasis keuntungan (profit oriented). Pembahasan mengenai fenomena crowdfunding di Indonesia masih terbatas. Selain itu, penelitian terkait risiko dari crowdfunding sangatlah minim. Pembahasan mengenai risiko crowdfunding berfokus pada aspek ekonomi. Terlebih lagi, belum pernah ada literatur 
ilmiah sebelumnya yang membahas mengenai risiko dari aspek dehumanisasi pada crowdfunding.

\section{Tujuan Penelitian}

Sebagaimana yang telah tercantum pada pendahuluan, penelitian ini bertujuan untuk mengenalkan crowdfunding, membahas fenomena crowdfunding di Indonesia, menganalisis potensi risiko, terutama risiko dehumanisasi pada crowdfunding, dan menemukan solusi untuk meminimalisasi risiko dehumanisasi dalam model manajemen donatur crowdfunding (Crowdfunding's Donor Relationship Management).

\section{Metode Penelitian}

Metode penelitian yang digunakan adalah penelitian deskriptif, yaitu penelitian yang menggambarkan situasi, kondisi sosial, atau hubungan secara detail (Rahayu, 2013) dan memaparkan fenomena yang ada tanpa memanipulasi fenomena tersebut serta tidak menguji hipotesis ataupun prediksi (Savitri, Nuswantara, \& Zahrok, 2016). Penelitian ini dilakukan dengan kajian literatur ilmiah terkait crowdfunding yang jumlahnya masih terbatas dan riset secara daring untuk meninjau fenomena crowdfunding di Indonesia.

Data yang didapatkan dari riset tersebut berupa data kuantitatif dan kualitatif. Sifat data adalah data sekunder, dimana penulis mendapatkannya dari riset daring.

Analisis data dilakukan dengan mengamati fenomena crowdfunding di Indonesia. Hasil dari analisa data adalah penyusunan suatu model manajemen donatur crowdfunding.

\section{Hasil Penelitian dan Pembahasan}

Sebagai fenomena yang tergolong baru, definisi crowdfunding masih terbuka untuk dirumuskan lebih lanjut (Forbes \& Schaefer, 2017). Pada umumnya, crowdfunding didefinisikan sebagai proses inisiasi proyek yang membutuhkan investasi dan meminta dana kepada sekelompok besar orang (crowd) dan koneksinya (Risdahl, 2011) sebagai penyandang dana untuk membiayainya (Forbes \& Schaefer, 2017). Crowdfunding menjadi alternatif sumber pendanaan eksternal bagi penggalang dana (Belleflamme et al., 2013) yang baru (Henry, 2016) jika kesulitan mendapatkan dana dari sumber tradisional seperti bank, angel investor, dan pasar saham (Brown et al., 2016). Penelitian empiris melaporkan pertumbuhan jumlah dana yang sangat besar yang dikumpulkan melalui crowdfunding (Belleflamme et al., 2013).

Crowdfunding membantu penggalang dana mengadopsi pendekatan baru dalam menjalankan inisiatif/kampanye dan mengelola usaha, serta pengembangan bisnis baru (Belleflamme et al., 2013).

Crowdfunding merupakan konsep yang lebih spesifik dari crowdsourcing, dimana crowdsourcing adalah pelibatan crowd (kerumunan/sekelompok individu) untuk mendapatkan ide, umpan balik, dan solusi untuk mengembangkan aktivitas perusahaan (Belleflamme et al., 2013) maupun suatu inisiatif melalui publikasi atau pengumuman terbuka di internet. Publikasi ini efisien bagi crowdsourcing pada umumnya, tetapi akan sensitif pada crowdfunding (Belleflamme et al., 2013) karena terkait dengan pendanaan. Oleh karena itu, sebagian besar inisiatif tidak menawarkan saham namun memberikan jenis penghargaan lainnya, seperti produk, keanggotaan, mekanisme pembagian 
keuntungan di mana orang banyak menerima sebagian keuntungan yang telah ditentukan sebelumnya dari penjualan produk untuk investasi mereka (Belleflamme et al., 2013).

Crowdfunding melibatkan pengumuman terbuka, sebagian besar melalui Internet, untuk penyediaan sumber keuangan baik dalam bentuk sumbangan atau dengan imbalan produk di masa depan atau beberapa bentuk penghargaan untuk mendukung inisiatif untuk tujuan tertentu (Belleflamme et al., 2013). Aktor utama dari crowdfunding yaitu penggalang dana (peminik insiatif/proyek), platform crowdfunding, dan donatur (Rahayu, 2013).

Crowdfunding bertujuan untuk mengumpulkan uang untuk investasi yang biasanya menggunakan jejaring sosial (Belleflamme et al., 2013). Crowdfunding membantu organisasi dan individu (Brown et al., 2016) mendapatkan dana dari alih-alih dari sekelompok investor dengan dana besar, melainkan dari khalayak luas dengan dana kecil dari masing-masing individu (Belleflamme et al., 2013). Tidak hanya untuk menggalang dana, crowdfunding juga dapat bertujuan sebagai sarana pemasaran organisasinya (Brown et al., 2016).

Konsep crowdfunding dapat diimplementasikan di masa kini karena beberapa faktor (Risdahl, 2011), yaitu

1. Semakin banyak orang mempercayai metode pembayaran secara daring.

2. Jaringan sosial semakin memungkinkan orang untuk saling berkomunikasi kepada koneksinya dengan mudah.

3. Teknologi yang ada sekarang ini memungkinkan pembayaran daring dilakukan dengan aman
4. Komunitas dan crowd daring dapat dengan mudah bersama-sama bertemu secara daring untuk menginisiasi suatu proyek.inisiasi tertentu.

5. Semakin banyak kisah sukses terkait proyek/inisiatif yang didanai dengan crowdfunding.

Crowdfunding terkait dengan pengalaman komunitas yang memberikan manfaat bersama bagi partisipannya. Keuntungan lain yang didapat oleh penyandang dana adalah privasi (Belleflamme et al., 2013)

\section{Skema Crowdfunding}

Skema crowdfunding antara lain, yaitu penggalang dana meminta dana untuk memesan produknya sebelum produk dibuat (pre-ordering) (Belleflamme et al., 2013). Skema lain yaitu pemberi dana secara kolektif memberi dana mendapatkan kompensasi yaitu pengembalian finansial seperti ekuitas, saham mirip ekuitas, atau deviden (equity-based) (Forbes \& Schaefer, 2017; Bretschneider, Knaub, \& Wieck, 2014) atau untuk berbagi keuntungan di masa mendatang (profitsharing) (Belleflamme et al., 2013). Skema lain yakni investasi dengan imbalan hadiah atau produk (reward-based) dan peminjaman peer-to-peer (lending-based) (Forbes \& Schaefer, 2017; Bretschneider et al., 2014) serta pemberian donasi (donation-based) (Forbes \& Schaefer, 2017).

Skema pre-ordering yaitu penggalang dana mengundang penyandang dana untuk memesan produk di awal, dengan tujuan untuk mengumpulkan modal untuk memproduksi produk yang bersangkutan. Hal tersebut memungkinkan terjadinya perbedaan harga pre-order untuk pemberi dana dengan harga normal (harga untuk produk 
yang sudah dipasarkan) bagi konsumen biasa (Belleflamme et al., 2013). Pemberi dana mau membayar harga lebih demi mendapatkan produk lebih awal daripada konsumen regular. Namun, seiring meningkatnya kebutuhan modal, penggalang dana terpaksa mengubah skema penetapan harga optimal untuk menarik lebih banyak pre-order, sehingga profitabilitas inisiatif crowdfunding menurun secara signifikan berdasarkan model derivatif (Belleflamme et al., 2013).

Sedangkan skema profit-sharing, penggalang dana meminta pemberi dana untuk menyediakan uang sebagai imbalan atas keuntungan masa depan atau sekuritas ekuitas. Dalam skema ini, para pemberi dana memutuskan untuk membeli atau tidak membeli produk jika sudah dipasarkan (Belleflamme et al., 2013). Skema ini menjadi lebih menguntungkan dengan jumlah yang lebih besar. Hal ini karena jumlah yang lebih besar mendorong penggalang dana meminta lebih banyak individu untuk berpartisipasi dalam pembiayaan, dengan sedikit pengaruh pada sebagian kecil keuntungan yang harus diberikan untuk mendapatkan pembiayaan (Belleflamme et al., 2013).

Skema donasi yaitu mekanisme pembagian keuntungan menyerupai sumbangan, bentuk pembiayaan yang tidak biasa. Ketika para penyandang dana berharap untuk menjadi konsumen di masa depan dan memberi manfaat bagi masyarakat, mereka dapat mendukung sebuah proyek dengan menyumbangkan dana sehingga pengusaha dapat meneruskan proyeknya. Penyandang dana menyumbang karena mereka mengharapkan konsumen atau menikmati manfaat masyarakat yang memadai (Belleflamme et al., 2013).

\section{Manfaat Crowdfunding}

Bagi penggalang dana, selain mendapatkan dana, juga mendapatkan manfaat lainnya. Untuk penggalang dana sebagai pengusaha, mereka dapat umpan balik dari pemberi dana mengenai produk yang akan diluncurkan (Forbes \& Schaefer, 2017). Selain itu, dapat menjadi alat pemasaran dan branding produk (Brown et al., 2016).

Penyandang dana juga dapat leluasa memilih inisiatif yang akan didanai melalui platform crowdfunding (Rahayu, 2013).

\section{Crowdfunding di Indonesia}

Crowdfunding di Indonesia mulai berkembang sejak awal tahun 2012 (Rahayu, 2013), ditandai dengan berdirinya platform crowdfunding lokal yaitu Patungan.net dan Wujudkan.com. Potensi berkembangnya crowdfunding di Indonesia sangatlah besar. Faktor-faktor dari potensi perkembangan crowdfunding di Indonesia antara lain filantropi masyarakat di bidang sosial yang tinggi dan meningkatnya jumlah penggunaan internet di Indonesia (Rahayu, 2013). Sedangkan hal-hal yang membuat crowdfunding ini menarik adalah mekanisme yang mudah, tidak bermodalkan modal besar, dan bisa untuk semua jenis inisiatif/proyek (Rahayu, 2013).

Selain itu, ada beberapa organisasi penggalang dana yang memilih untuk memiliki situs web crowdfunding-nya sendiri, tanpa melalui platform crowdfunding, seperti Aksi Cepat Tanggap (www.act.or.id) dan Badan Amil Zakat Nasional (www.pusat.baznas.go.id). Walaupun dikemudian hari ternyata beberapa organisasi yang memiliki situs web crowdfunding-nya sendiri juga turut menjadi penggalang dana melalui platform crowdfunding lain. 


\section{Platform Crowdfunding Lokal di Indonesia}

Sejak 2011, beberapa platform crowdfunding yang didirikan oleh orang Indonesia antara lain gagas.web.id, Mari Membantu, Linimas(s)a, Patungan.net, Wujudkan (Rahayu, 2013), modal.in, BursaIde.com, Kitabisa.com, Ayo Peduli, dan Gandeng Tangan. Selain itu, juga berdiri platform crowdfunding berbasis website yang dapat diakses melalui aplikasi Facebook, yaitu GoFund (Rosalina, Handojo, \& Wibowo, 2012)

Sebagai salah satu pionir platform crowdfunding di Indonesia, Patungan.net berupaya mempromosikan inisiatif/proyek dari penggalang dana dengan cara merangkul penyandang dana dengan mengombinasikan antara daring dan konvensional (Rahayu, 2013). Hal ini dilakukan mengingat metode crowdfunding belum familiar pada saat itu. Penggalang dana akan mempresentasikan proyeknya secara langsung kepada calon penyandang dana difasilitasi oleh Patungan.net dan Patungan.net mengambil komisi 5\% dari nilai proyek yang berhasil (Rahayu, 2013).

Salah satu platform crowdfunding lokal lainnya adalah Kitabisa.com. Platform yang berdiri pada tahun 2013 ini menerapkan kebijakan open platform, dimana setiap orang bebas membuat proposal inisiatif penggalangan dana selama melengkapi syarat verifikasi identitas dan tidak melanggar hokum di Indonesia. Kitabisa.com adalah platform berbasis sosial, dimana kampanye yang masuk murni bertujuan untuk kepentingan sosial. Seperti Patungan.com, Kitabisa.com menetapkan biaya administrasi sebesar 5\% dari jumlah donasi, kecuali inisiatif tentang bencana alam dan zakat. Per 22 Juni 2017, manajemen Kitabisa.com mengklaim bahwa, melalui platform-nya, sebanyak 5.505 kampanye telah berhasil didanai dengan
Rp113.320.437.639,00 dana yang terkumpul. Selain itu, anggota penyandang dana yang tergabung pada platform ini sebesar 315.998 orang ("Kitabisa.com," 2017).

GandengTangan.org adalah platform crowdfunding yang ditujukan untuk memberikan akses pembiayaan kepada usaha kecil menengah. Penyandang dana akan mendapatkan imbal balik karena ini crowdfunding ini berskema crowdlending, sehingga dana yang dipinjamkan adalah bentuk suatu investasi. Imbal hasil yang diberikan sebesar $12 \%$ per tahun tanpa dikenakan biaya apapun dengan minimal pembiayaan sebesar Rp50.000,00 dan deposit sebesar Rp500.000,00. Untuk penggalang dana, dana maksimal yang dapat diajukan adalah sebesar Rp25.000.000,00 (“gandengtangan," 2017).

\section{Kegagalan Beberapa Platform Crowdfunding Lokal di Indonesia}

Beberapa platform crowdfunding lokal mengalami masalah. Salah satu studi kasus pada platform crowdfunding Patungan.net juga hiatus sejak 5 Agustus 2015. Dalam rilisnya, Patungan.net sedang menggodok mekanisme crowdfunding baru. Hingga tahun 2017, belum ada tanda-tanda bahwa Patungan.net akan kembali beroperasi (www.patungan.net).

Hal yang serupa juga terjadi pada Wujudkan.com. Platform crowdfunding ini harus berhenti beroperasi pada 31 Maret 2017. Dalam press release-nya, Wujudkan.com berhenti beroperasi dikarenakan jumlah inisiatif yang sukses tidak sampai $12 \%$ serta biaya operasional yang terlalu besar (https://wujudkanid.wordpress.com /2017/02/01/sebuah-pengumuman-penting/). 


\section{Risiko Crowdfunding}

Sebagian besar inisiatif crowdfunding secara dramatis gagal dengan $81 \%$ inisiatif yang gagal mencapai kurang dari 20\% dari target pendanaan mereka (Forbes \& Schaefer, 2017).

risiko crowdfunding dari sudut pandang penggalang dana antara lain adalah memerlukan usaha yang lebih besar, tidak hanya membuat inisiasi untuk mencari penggalang dana, tetapi juga harus melayani penggalang dana dengan produk hasil inisiasi dan perkembangan dari produk tersebut (Brown et al., 2016). Selain itu ada juga reputational risks, seperti kegagalan inisiatif mencapai target pendanaan, produk yang terlambat/gagal diselesaikan, maupun tidak sesuai dengan harapan pemberi dana (Brown et al., 2016).

Selain itu, masuknya perusahaan besar untuk ikut membuat inisiatif pada platform crowdfunding juga memiliki risiko. Ia harus bersaing dengan perusahaan kecil, start-up, organisasi non-profit, maupun individu yang hanya bergantung pada crowdfunding untuk mendanai inisiatifnya (Brown et al., 2016). Sedangkan platform crowdfunding tidak memiliki pengelompokan inisiator, sehingga semua inisiator bersaing di tempat yang sama. Sedangkan pihak pemberi dana lebih mempertimbangkan mendukung inisiatif dari perusahaan kecil, start-up, organisasi non-profit, maupun individu (Brown et al., 2016).

\section{Risiko Dehumanisasi}

risiko dehumanisasi berpotensi terjadi pada crowdfunding. Beberapa prinsip penggalangan dana seperti yang dikemukakan Quebral, Terol, dan Roman dalam Rahayu (Rahayu, 2013) adalah komunikasi dan prospek. Hal ini penting untuk memastikan akuisisi dan keberlanjutan penyandang dana pada suatu inisiatif. Faktor lainnya yaitu membangun hubungan (relationship building). Pentingnya mengem-bangkan hubungan yang sudah ada dan membangun hubungan baru dengan penyandang dana (Rahayu, 2013).

Intinya, semua pihak yang terlibat (penggalang dana, penyandang dana, dan platform) pada crowdfunding harus memiliki nilai, kepentingan, dan komitmen yang sama untuk mewujudkan suatu inisiatif. Salah satu contoh dehumanisasi pada faktor-faktor tersebut adalah kurangnya usaha penggalang dana untuk akuisisi calon penyandang dana yang sesuai dengan jenis inisiatifnya. Setiap platform memiliki ciri khas masing-masing. Sebagai contoh Kitabisa.com untuk kegiatan sosial dan GandengTangan.org untuk pendanaan UKM.

Kemudian, kurangnya komunikasi antar penggalang dan penyandang dana. Dikarenakan teknologi crowdfunding sangat praktis, sehingga penggalang dana hanya mempublikasikan proposalnya secara daring. Lalu setelah dana tercukupi, dan inisiatif selesai begitu saja. Penggalang dana tidak berkomunikasi dengan penyandang dana. Hal ini memungkinkan penyandang dana untuk tidak berminat mendanai inisiatif-inisiatif lainnya, terutama yang diinisiasikan oleh penggalang dana tersebut. Hal ini dapat berdampak buruk baik pada penggalang dana maupun pada platformcrowdfunding yang bersangkutan.

\section{Model Manajemen Donatur Crowdfunding}

Model Manajemen Donatur Crowdfunding diperlukan untuk menjalin hubungan yang lebih humanis antara pemonon dana dengan donatur. 
Model Manajemen Donatur Crowdfunding memperhatikan modus-modus esensial manusia menurut Herschel dalam Nugroho (Nugroho, 2011), karena jika modus-modus tersebut ditinggalkan, maka akan menyebabkan manusia berhenti menjadi manusia yang humanis. Modus-modus esensial kemanusiaan tersebut antara lain (Nugroho, 2011):

1. Keberhargaan (preciousness)

Keberhargaan terkait dengan kita sebagai manusia memandang manusia lain bukan sekedar makhluk, tetapi dipandang sebagai sesama manusia yang dihargai, diperhatikan, dan disayangi.

\section{Keunikan (uniqueness)}

Setiap manusia unik, berbeda dengan yang lain. Memiliki kebebasan untuk mengambil keputusan dalam setia fase kehidupannya. Setiap pribadi mempunyai jalan hidup yang tidak akan identic dengan manusia lainnya.

3. Kesempatan (opportunity)

Setiap manusia memiliki kesempatan untuk mengembangkan kepasitasnya tanpa batas. Humanisasi berpedoman pada mengakui potensi-potensi manusia tersebut dan mengaktualisasikannya.

4. Tidak pernah final (nonfinality)

Manusia pada hakikatnya berada pada dua kutub ketidakpastian dan indeterminasi melawan kutub finalitas dan determinasi. Manusia memiliki dua sisi, misalnya mengikuti sekaligus melawan arus, tunduk sekaligus memberontak (Nugroho, 2011). Humanisasi adalah mengakui hal tersebut.

5. Proses dan peristiwa (events)

Humanisasi pada modus ini adalah saat manusia menyadari bahwa ia memiliki peran penting bukan hanya pada proses (sesuatu yang terstandar dan monoton) tetapi juga memiliki peran pada suatu peristiwa (kejadian unik, tidak terulang, membutuhkan suatu pengambilan keputusan tertentu). Bukan hanya sebuah objek yang menjalani hidup dengan statis.

6. Keheningan (solitude) dan solidaritas (solidarity)

Keheningan diperlukan manusia sebagai fase pemulihan dan pencarian akan solidaritas sejati. Sedangkan untuk solidaritas, manusia akan merasa dirinya bermakna jika memiliki sesuatu yang ia bagikan ataupun terkait dengan sesamanya.

7. Ketimbalbalikan (reciprocity)

Martabat manusia ada pada kekuatan timbal balik. Menerima dan memberi adalah esensi dari kemanusiaan itu sendiri. Kepekaan sosial terhadap sesama dan hasrat untuk memberi adalah salah satu contoh humanisasi dari sisi ketimbalbalikan.

8. Kekudusan (sanctity)

Manusia pada hakikatnya memiliki kepekaan akan suatu kesakralan. Merasa bahwa kehidupan manusia ada yang menciptakannya.

Model Manajemen Donatur Crowdfunding pada dasarnya mencakup hal-hal berikut ini.

\section{Pra Crowdfunding}

a. Riset pemasaran

Untuk dapat mengakuisi penyandang dana, penggalang dana harus dapat mengetahui dimana posisi crowd yang sesuai dengan inisiatifnya dengan cara memilih platform crowdfunding yang tepat.

b. Proposal inisiatif yang menarik

Sebagaimana proposal pada umumnya, penting untuk membuat proposal ini semenarik mungkin untuk dapat dilirik oleh 
penyandang dana. Proses pembuatan proposal ini menantang penggalang dana untuk mengembangkan potensinya dan mengaktualisasikannya, sesuai dengan modus esensial manusia, yaitu kesempatan.

2. Saat Crowdfunding berlangsung

a. Daftar informasi detail mengenai penggalang dana

Pihak penggalang dana maupun platform crowdfunding harus memiliki data penggalang dana, yang bisa digunakan untuk komunikasi selama proses crowdfunding berlangsung hingga pasca crowdfunding. Dengan selalu menjaga komunikasi, penyandang dana akan merasa dihargai.

b. Penawaran imbal balik

Selain model crowdlending yang memang mengharuskan penggalang dana untuk memberi imbal balik sesuai dengan kesepakatan kepada penyandang dana setelah inisiatifnya berhasil dijalankan, pada social crowdfunding juga dimungkinkan memberikan imbal balik kepada penyandang dana. Penawaran imbal balik ini sesuai dengan modul esensial manusia, yaitu ketimbalbalikan.

Gambar 1

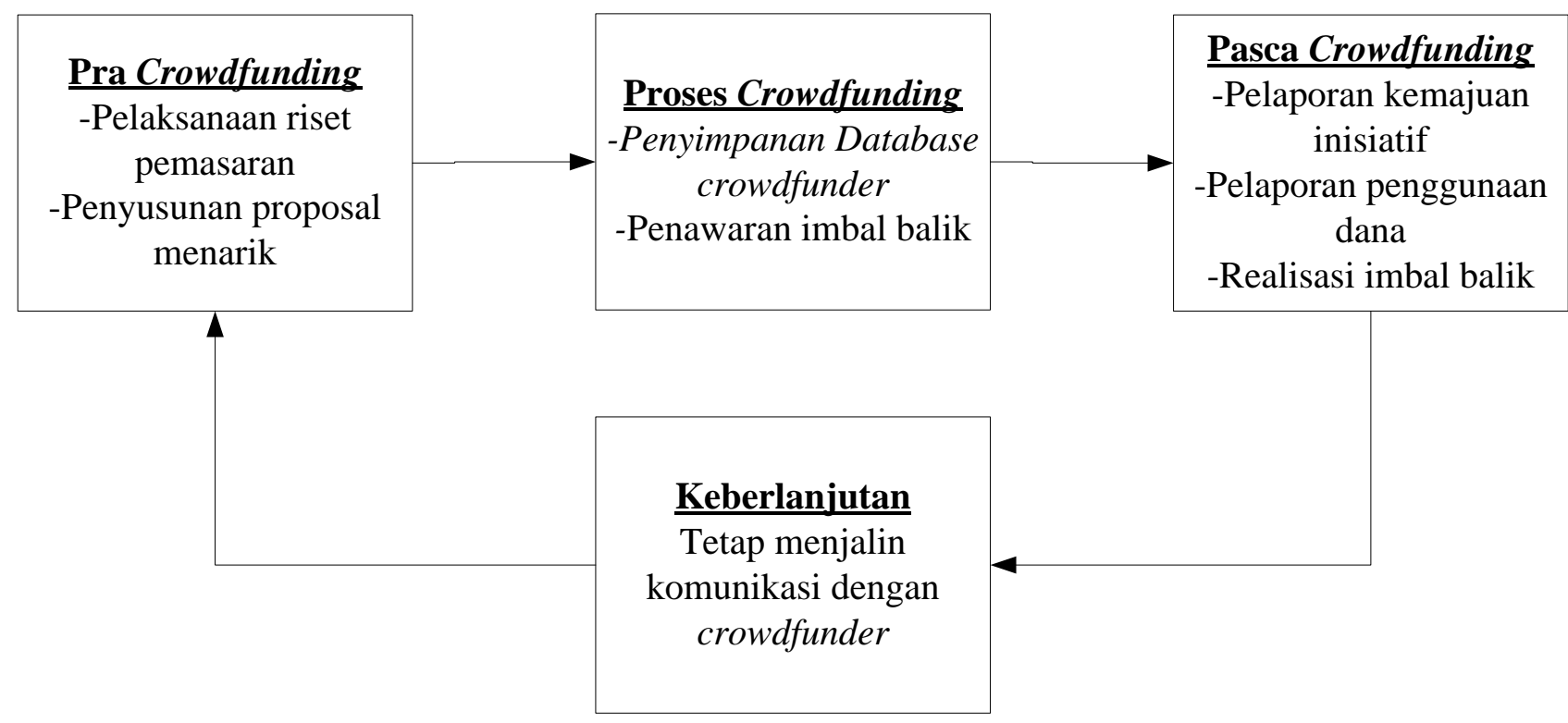

(Ket.: Model Manajemen Donatur Crowdfunding)

\section{Pasca Crowdfunding}

a. Laporan kemajuan

Penggalang dana wajib melaporkan kemajuan/perkembangan inisiatifnya untuk membangun kepercayaan terhadap penyandang dana.

b. Laporan penggunaan dana
Laporan keuangan wajib dilaporkan untuk menjamin transparansi dan akuntabilitas suatu inisiatif .

c. Ucapan terima kasih

Untuk menghargai penyandang dana, maka pesan-pesan semacam ucapan terima kasih sangatlah penting dilakukan. 
d. Realisasi pemberian imbal balik sesuai dengan kesepakatan

Hal ini merupakan komitmen yang harus dipenuhi untuk menjaga rasa saling percaya antara kedua belah pihak

4. Keberlanjutan

a. Tetap menjalin komunikasi dengan donatur Sebaiknya platform crowdfunding menyediakan sarana komunikasi antara penggalang dan pemberi dana, misalnya surat elektronik, maupun aplikasi pesan yang mudah untuk dioperasikan.

\section{Kesimpulan}

Pemanfaatan teknologi dalam penggalangan dana, baik untuk pendanaan berbasis profit maupun untuk kegiatan sosial sangatlah penting karena mempermudah proses pendanaan tersebut. Namun, sebagai manusia, esensi kemanusiaan tidak benar jika ditinggalkan hanya karena terlena dengan kemudahan teknologi. Pada crowdfunding, beberapa kasus kegagalan pendanaan terjadi karena rendahnya hubungan interpersonal yang kurang kuat antara pemohon dana dengan donatur. Oleh sebab itu, diharapkan model manajemen donatur crowdfunding dapat membantu meminimalisasi risiko dehumanisasi sekaligus meningkatkan potensi keberhasilan penggalangan dana untuk mencapai targetnya, dan meningkatnya donatur loyal, yang dapat membantu penggalang dana untuk kegiatan penggalangan dana di masa mendatang.

\section{Referensi}

Belleflamme, P., Lambert, T., \& Schwienbacher, A. (2013). Crowdfunding:
Tapping the right crowd. Journal of Business Venturing. http://doi.org/10.1016/j.jbusvent.2013.07.0 03

Bretschneider, U., Knaub, K., \& Wieck, E. (2014). Motivations for Crowdfunding: What Drives the Crowd to Invest in Startups? In European Conference on Information Systems (ECIS) (accepted for publication). Te Aviv, Israel.

Brown, T. E., Boon, E., \& Pitt, L. F. (2016). Seeking funding in order to sell: Crowdfunding as a marketing tool. Business Horizons. http://doi.org/10.1016/j.bushor.2016.11.00 4

Forbes, H., \& Schaefer, D. (2017). Guidelines for Successful Crowdfunding. In Procedia CIRP (Vol. 60, pp. 398-403). Elsevier B.V. http://doi.org/10.1016/j.procir.2017.02.021

gandengtangan. (2017). Retrieved from https://gandengtangan.org

Henry, G. F. (2016). Funding innovation: Moving the business forward. Surgery, 160(5),

$1135-1138$. http://doi.org/10.1016/j.surg.2016.06.056

Kitabisa.com. (2017). Retrieved from https://kitabisa.com/\#_=

Nugroho, E. C. (2011). Menghargai ModusModus Esensial Manusia sebagai Upaya Mengatasi Problem Dehumanisasi di Indonesia. HUMANIKA, 14. Retrieved from

http://download.portalgaruda.org/article.ph $\mathrm{p}$ ? article $=23223 \& \mathrm{val}=1313 \&$ title $=$ Mengha rgai Modus-Modus Esensial Manusia sebagai Upaya Mengatasi Problem Dehumanisasi di Indonesia

Rahayu, C. C. (2013). Penggalangan Dana Model Crowdfunding di Indonesia. Universitas Indonesia.

Risdahl, A. S. (2011). The Complete Idiot's Guide to Crowdsourcing. New York: Alpha Books.

Rosalina, Handojo, A., \& Wibowo, A. (2012). Aplikasi Crowdfunding Sebagai Perantara 
Penggalangan Dana Berbasis Website dan Facebook Application. Komputer, 2(Jaringan Komputer), 1-5.

Savitri, E. D., Nuswantara, K., \& Zahrok, S. (2016). Sikap Pilihan Bahasa Pelaku Ekonomi Berdasarkan Tinjauan UndangUndang dan Peraturan Pemerintah. Jurnal Sosial Humaniora, 9, 156-169. 